\title{
ANALISIS KINERJA HIGH PRESSURE HEATER (HPH) TIPE SHELL AND TUBE HEAT EXCHANGER
}

\author{
Devia Gahana Cindi Alfian ${ }^{1}$, Didik Supriyadi ${ }^{2}$ \\ ${ }^{1}$ Institut Teknologi Sumatera \\ ${ }^{2}$ Institut Teknologi Sumatera
}

\begin{abstract}
Heat exchanger is one of the supporting production equipment that transfer the heat from one fluid to another fluid. One example of a heat exchanger in power plant industry is High Pressure Heater (HPH). HPH is high pressure feedwater heater that use hot steam turbine extraction before entering the economizer on boiler to reduce the work of boiler. This research was conducted to determine the effective efficiency of High Pressure Heater at Power Plant Industry. This efficiency determination is based on thermodynamics and heat transfer analysis with Log Mean Temperature Difference (LMTD) method and Number of Transfer Unit (NTU) method. The analysis is to determining the effective heat transfer, overall heat transfer coefficient $(U)$, Effectiveness and the analysis of pressure drop $(\Delta P)$. The analysis results obtained the efffective heat transfer of $37.013 \mathrm{~kW}$, overall heat transfer coefficient $(U)$ of 502,48, effectiveness of 0,47 and the number of pressure drop of $23.498,06 \mathrm{~Pa}$.
\end{abstract}

Keyword:High Pressure Heater (HPH), Heat Exchanger, Shell and Tube, Performance

\section{Pendahuluan}

Proses produksi energi listrik dalam sistem pembangkit dipengaruhi oleh peralatan utama yang ada pada Pembangkit Listrik Tenaga Uap (PLTU), misalnya; boiler atau ketel uap, turbin, kondensor dan generator. Proses produksi dimulai dengan masuknya air pengisi boiler yang berupa $\mathrm{H}_{2} \mathrm{O}$ dengan proses treatment dimana air pengisi boiler ini sebelumnya melalui Low Pressure Heater (LPH), deaerator, dan High Pressure Heater (HPH). Selanjutnya air tersebut masuk ke boiler untuk dipanaskan sampai menjadi uap kering untuk menggerakkan turbin uap dan generator sehingga menghasilkan tegangan listrik.

High Pressure Heater merupakan alat pemanas air pengisi lanjut bertekanan tinggi yang menggunakan uap panas hasil ekstraksi turbin sebagai media pemanasnya sebelum masuk economizer pada boiler. Komponen ini terdiri dari sebuah shell silindris di bagian luar dan sejumlah tube (tube bundle) di bagian dalam dimana temperatur fluida di dalam shell berbeda dengan temperatur di dalam tube sehingga mengakibatkan terjadinya perpindahan panas antar aliran fluida. Sebagai salah satu komponen di PLTU, HPH memiliki peranan yang sangat penting dalam menjaga temperatur air pengisi yang masuk kedalam boiler, maka semakin baik nilai efisiensi dari High Pressure Heater (HPH) akan meningkatkan efisiensi dari boiler sehingga dapan menghemat biaya operasional harian dari PLTU.

Dalam aplikasi di dunia Industri High Pressure Heater (HPH) merupakan salah satu contoh alat penukar panas yang dikenal dengan istilah Heat Exchanger (HE). Heat Exchanger (HE) merupakan alat penukar kalor yang berfungsi untuk mengubah temperatur fasa suatu jenis fluida. Proses tersebut terjadi dengan memanfaatkan proses perpindahan panas/kalor dari suatu fluida bertemperatur tinggi menuju fluida bertemperatur rendah. Jenis alat penukar panas digunakan pada penelitian adalah Shell and Tube Heat Exchangertipe U-Tube.

Beberapa penelitian yang telah dilakukan mengenai analisa Heat Exchanger dapat dilihat pada Tabel 1 berikut ini:

Tabel 1. Hasil Penelitian Terdahulu

\begin{tabular}{|c|l|l|}
\hline Tahun & Penulis & \multicolumn{1}{|c|}{ Hasil Penelitian } \\
\hline 2011 & Min Li & $\begin{array}{l}\text { Penelitian ini dilakukan dengan melakukan analisis } \\
\text { kinerja secara Termodinamika pada borehole ground }\end{array}$ \\
& & $\begin{array}{l}\text { heat exchangerstipe U-tube dengan metode minimisasi } \\
\text { generasi entropi.Penelitian ini mengembangkan dua } \\
\text { ekspresi eksplisit untuk dimensi panjang dan Reynolds }\end{array}$ \\
\hline
\end{tabular}




\begin{tabular}{|c|c|c|}
\hline Tahun & Penulis & Hasil Penelitian \\
\hline & & $\begin{array}{l}\text { Numberdengan meminimalkan generasi entropi. Hasil } \\
\text { penelitian ini menyimpulkan bahwa parameter optimal } \\
\text { termodinamika pada borehole heat exchangers dapat } \\
\text { ditentukan dengan menggunakan metode minimisasi } \\
\text { generasi entropi. }\end{array}$ \\
\hline 2013 & I. Bizzy & $\begin{array}{l}\text { Dalam penelitian ini, dilakukan perancangan berupa } \\
\text { perhitungan dimensi alat penukar kalor tipe shell and } \\
\text { tube menggunakan metode analisa komputerisasi Heat } \\
\text { Transfer Research Inc. (HTRI) dan metode analisa } \\
\text { perhitungan manual. Hasil analisa perhitungan dimensi } \\
\text { diperoleh bahwa alat penukar kalor yang dirancang } \\
\text { sudah memenuhi syarat minimum dari faktor pengotoran } \\
\text { yang telah ditetapkan. Kualitas alat penukar kalor akan } \\
\text { meningkat sebanding dengan menurunnya nilai faktor } \\
\text { pengotoran, menurunnya nilai penurunan tekanan dan } \\
\text { besarnya dimensi alat penukar kalor. }\end{array}$ \\
\hline 2014 & R. Veriyawan & $\begin{array}{l}\text { Penelitian ini melakukan optimasi pada desain heat } \\
\text { exchanger tipe shell-and-tube dengan menggunakan } \\
\text { metode Algoritma particle swarm optimization (PSO). } \\
\text { Tujuannya adalah untuk mengoptimasikan nilai koefesien } \\
\text { perpindahan panas keseluruhan dengan mendapatkan } \\
\text { nilai terbaik. Dari hasil optimasi pada tiga HE didapatkan } \\
\text { nilai U dan A secara berturut-turut; HE E-1111 } 472 \\
\mathrm{~W} / \mathrm{m}^{2} \mathrm{C} \text { dan } 289 \mathrm{~m}^{2} \text {; pada HE E- } 1107174 \mathrm{~W} / \mathrm{m}^{2} \mathrm{C} \text { dan } \\
265 \mathrm{~m}^{2} \text {; dan HE E-1102 } 618 \mathrm{~W} / \mathrm{m}^{2} \mathrm{C} \text { dan } 574 \mathrm{~m}^{2} \text {. Nilai } \\
\text { perpindahan panas keseluruhan yang telah dioptimasi } \\
\text { sesuai dengan fungsi objektif dapat dikatakan HE shell- } \\
\text { and-tube mencapai titik optimal. }\end{array}$ \\
\hline 2017 & J. Sudrajat & $\begin{array}{l}\text { Pada penelitian ini dilakukan analisis heat exchanger } \\
\text { untuk mengetahui pengaruh fouling terhadap laju } \\
\text { perpindahan panas aktual dan efektivitas heat } \\
\text { exchanger. Analisis dilakukan dengan membuat } \\
\text { perhitungan parameter-parameter yang dibutuhkan. Dari } \\
\text { hasil perhitungan dan analisis menunjukkan bahwa } \\
\text { terjadi penurunan pada laju perpindahan panasnya } \\
\text { hingga sebesar } 0,411 \mathrm{~kW} \text { atau } 19,45 \% \text {, setara dengan } \\
\text { energi yang dihasilkan dari penggunaan solar sejumlah } \\
0,036 \text { liter selama satu jam. Fouling yang terjadi } \\
\text { mengalami kenaikan hingga sebesar } 0,561 \mathrm{~m} 2 . \mathrm{K} / \mathrm{kW} \text {. } \\
\text { Sedangkan efektivitasnya mengalami penurunan sebesar } \\
3,7 \% \text {. }\end{array}$ \\
\hline
\end{tabular}

Berdasarkan penelitian diatas banyak permasalahan yang terjadi dalam penukar panas yang disebabkan oleh beberapa faktor diantaranyapressure drop, perpindahan panas efektif, faktor pengotor dan lain-lain, sehingga evaluasi performansi penukar panas sangat diperlukan untuk meningkatkan kinerja alat penukar panas agar sesuai dengan kondisi operasi yang diharapkan.

\section{Metode}

Dalam menyelesaikan penelitian ini metode yang digunakan adalah metode analisa secara termodinamika dan perpindahan panas dengan menggunakan data yan diperoleh dari data operasi dan data konfigurasi performansi HPH serta berdasarkan data penunjang lainnya sehingga dapat diketahui nilai performansinya. 


\subsection{Spesifikasi Shell and Tube}

High Pressure Heater (HPH) yang akan dianalisa merupakan jenis Shell and Tube Heat Exchanger dengan spesifikasi berikut ini seperti terlihat pada Gambar 1:
a. Number of HP Heater : 5
b. Manufacturer : Mitsubishi
c. Surface Area $\quad: 1.102 \mathrm{~m}^{2}$
d. No. of tubeside passes : dua
e. Arrangement : horizontal

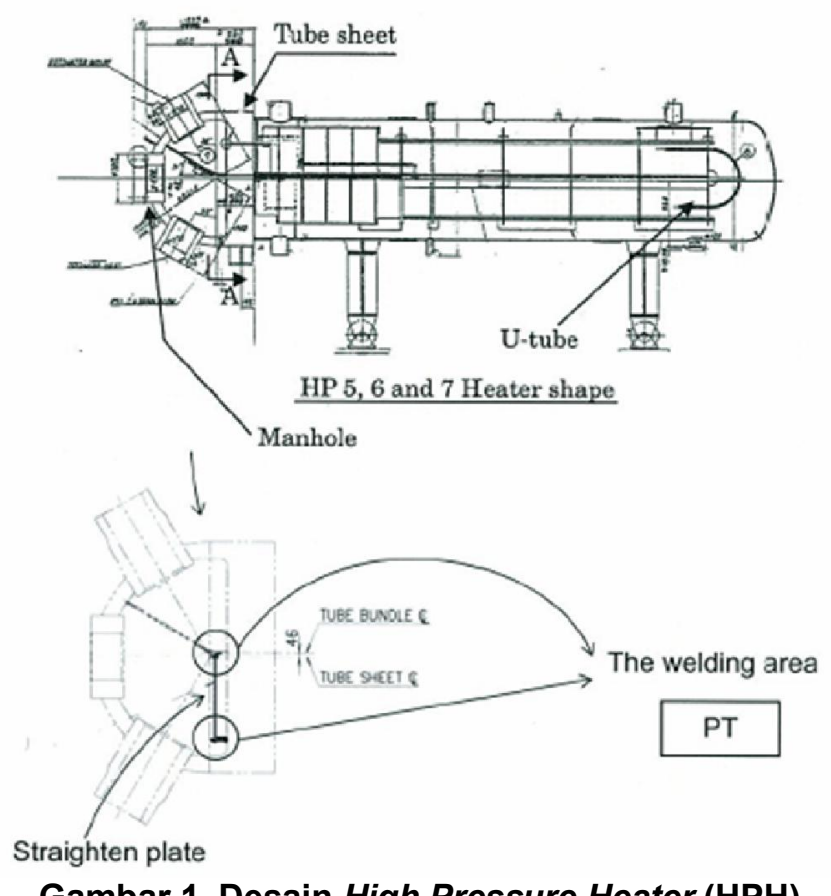

Gambar 1. Desain High Pressure Heater (HPH)

\subsection{Data Pendukung}

Data pendukung merupakan komponen yang cukup penting dalam proses analisa penelitian ini. Data-data tersebut yaitu data operasi pada PLTU serta data konfigurasi untuk mendapatkan data-data existing. Data lain sebagai penunjang penyelesaian analisa didapatkan dari textbook Fundamental Heat and Mass Transfer (Frank P. Incropera, David P. Dewitt), Termodinamika Teknik Jilid 1 (Michael J.Moran \& Howard N. Saphiro), Heat Exchangers Selection Rating and Thermal Design (Sadic Kakac, Hongtan Liu \& Anchasa Pramuanjaroenkij) dan sumber-sumber relevan lainnya.

Data operasi dari sisi shell dapat dilihat pada tabel 2, sedangkan data operaso dari sisi tube dapat dilihat pada tabel 3. . Data tersebut didapatkan dari PLTU. Pada HPH ini terdapat inputan berupa steam inlet dan drain inlet kemudian keluar dalam bentuk drain outlet.

Tabel2.Tabel Data Operasi sisi Shell (Hot Fluid)

\begin{tabular}{|c|c|c|}
\hline Steam Inlet & Drain Inlet & Drain Outlet \\
\hline $\mathrm{P}_{\mathrm{si}}=8,56$ Bar & $\mathrm{P}_{\mathrm{di}}=15,29 \mathrm{Bar}$ & $\mathrm{P}_{\mathrm{do}}=8,56 \mathrm{Bar}$ \\
\hline $\mathrm{T}_{\mathrm{si}}=332^{\circ} \mathrm{C}$ & $\mathrm{T}_{\mathrm{di}}=177,9^{\circ} \mathrm{C}$ & $\mathrm{T}_{\mathrm{do}}=152^{\circ} \mathrm{C}$ \\
\hline $\begin{array}{c}\mathrm{h}_{\mathrm{si}}=745,8 \mathrm{kcal} / \mathrm{kg}=3121 \\
\mathrm{~kJ} / \mathrm{kg}\end{array}$ & $\mathrm{h}_{\mathrm{di}}=754,21 \mathrm{~kJ} / \mathrm{kg}$ & $\begin{array}{c}\mathrm{h}_{\mathrm{do}}=153 \mathrm{Kcal} / \mathrm{kg}=640,58 \\
\mathrm{~kJ} / \mathrm{kg}\end{array}$ \\
\hline$\dot{m}_{s i}=12,74 \mathrm{~kg} / \mathrm{s}$ & $\dot{m}_{d i}=47,54 \mathrm{~kg} / \mathrm{s}$ & $\dot{m}_{d o}=60,29 \mathrm{~kg} / \mathrm{s}$ \\
\hline
\end{tabular}


Tabel 3.Tabel Data Operasi sisi Tube (Cold Fluid)

\begin{tabular}{|c|c|}
\hline Water Inlet & Water Outlet \\
\hline$\dot{m}_{w i}=324,5 \mathrm{~kg} / \mathrm{s}$ & \\
\hline $\mathrm{T}_{\mathrm{wi}}=146,4^{\circ} \mathrm{C}$ & $\mathrm{T} w o=173,2^{\circ} \mathrm{C}$ \\
\hline
\end{tabular}

Dari data yang ada pada tabel diatas dapat digambarkan distribusi temperaturnya pada T-S diagram pada Gambar 2 sebagai berikut:

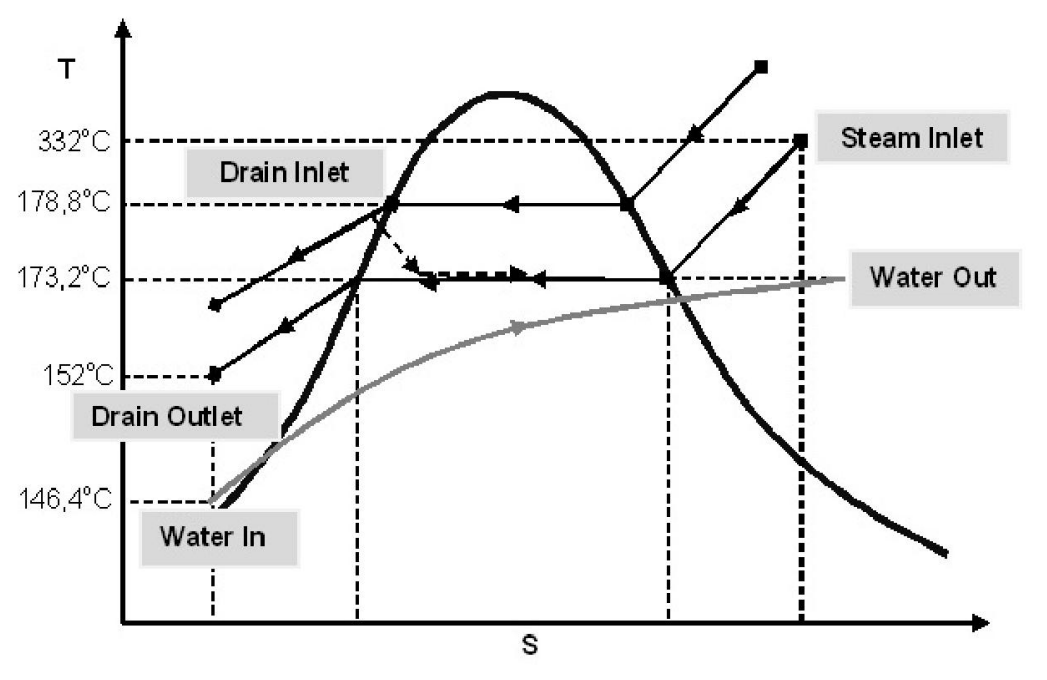

Gambar 2. Grafik T-S diagram padaHigh Pressure Heater (HPH)

\subsection{Langkah Analisa}

Flowchart analisa exising HPH dengan metode LMTD secara umum dapat dijelaskan sebagai berikut:

1. Menghitung laju perpindahan panas pada sisi shell dan sisi tube dengan data operasional yang sudah ada.

2. Mendapatkan properties feedwater masing-masing pada sisi shell dan sisi tube.

3. Menghitung koefisien konveksi masing-masing zona untuk mendapatkan nilai overall heat transfer calculation.

4. Menghitung nilai NTU untuk mendapatkan hasil unjuk kerja effectiveness.

5. Menganalisa pressure drop.

6. Analisa performa didapatkan.

Dari T-S diagram, dilakukan analisa berdasarkan balance energi sebagai berikut:

$$
\begin{gathered}
q_{h o t}=q_{\text {cold }} \\
{\left[\left(\dot{m}_{s i} \cdot h_{s i}\right)+\left(\dot{m}_{d i} \cdot h_{d i}\right)\right]-\left[\left(\dot{m}_{s i}+\dot{m}_{d i}\right) h_{d o}\right]=\dot{m}_{w} \cdot C p_{w}\left(T_{w o}-T_{w i}\right)}
\end{gathered}
$$

Analisa kesetimbangan massa untuk laju alir massa yang ada pada shell dilakukan dengan menggunakan formulasi: 


$$
\begin{gathered}
\dot{m}_{\text {inlet }}=\dot{m}_{\text {outlet }} \\
\dot{m}_{s i}+\dot{m}_{d i}=\dot{m}_{o u t}
\end{gathered}
$$

\subsubsection{Analisa Perpindahan Panas Sisi Tube}

Analisa laju perpindahan panas dilakukan dengan mendapatkan properties fluida sebagai berikut:

Aliran fluida yang berada di dalam tube dapat dibagi menjadi dua jenis berdasarkan milai Reynolds Number $(R e)$. Suatu fluida dapat dikatakan sebagai nilai laminar jika memiliki nilai $\operatorname{Re}<2300$ dan dikatakan memiliki jenis aliran Turbulent jika $R e \geq 2300$.

$$
\operatorname{Re}_{\text {tube }}=\frac{\rho_{\text {tube }} \cdot V_{\text {tube }} \cdot d i_{\text {tube }}}{\mu}
$$

Pada aliran laminar nilai nusset number didapatkan dari karakteristik fluidayang berada di dalam aliran tube yaitu $q$ " (heat flux) konstan, kondisi fully developed flow serta nilai Nusselt Number kontan tidak terpengaruh pada $\operatorname{Re}, \operatorname{Pr}$ dan axial location dapat di formulasikan sebagai berikut:

$$
\begin{gathered}
N u=\frac{h \cdot D}{k}=4,36 \text { (q" konstan) } \\
N u=3,66 \text { (Ts konstan) }
\end{gathered}
$$

Pada aliran turbulen nilai Nusset number dapat di formulasikan sebagai berikut:

$$
N u=0,023 \operatorname{Re}^{0,8} \operatorname{Pr}^{n}
$$

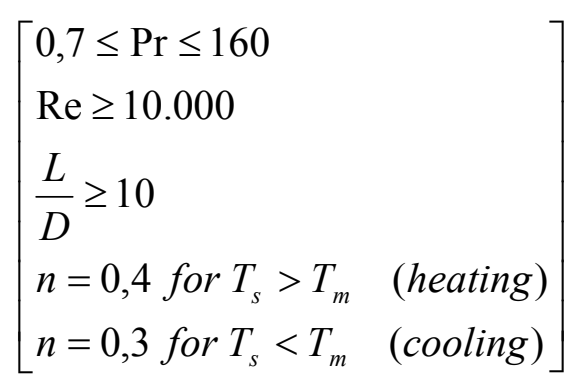

Sehingga nilai koefisien konveksi pada tube adalah:

$$
h i_{\text {tube }}=\frac{N u_{\text {tube }} \cdot k_{\text {tube }}}{d i_{\text {tube }}}
$$

\subsubsection{Analisa Perpindahan Panas Sisi Shell}

Analisa laju perpindahan panas dilakukan dengan mendapatkan properties fluida yang ada pada sisi shell dengan menggunakan tabel tekanan sifat air jenuh (Tabel 4) dengan data input sebagai berikut: 
Tabel 4.Tabel Data sisi Shell (Hot Fluid)

\begin{tabular}{|c|c|}
\hline \multicolumn{2}{|c|}{ Data pada sisi Shell } \\
\hline$P_{\text {shell }}$ & $8,56 \mathrm{bar}$ \\
\hline$T_{\text {avg }}$ & $515 \mathrm{~K}$ \\
\hline$\mu_{\text {shell }}$ & $1,77 \times 10^{5} \mathrm{Nm} / \mathrm{s}$ \\
\hline$k_{\text {shell }}$ & $3,797 \times 10^{2} \mathrm{~W} / \mathrm{mK}$ \\
\hline$C_{p}$ & $2207.043 \mathrm{~J} / \mathrm{kgK}$ \\
\hline
\end{tabular}

Analisa cross flow area sisi shell dapat dilakukan analisa sebagai berikut:

$$
A_{s}=\frac{0,5\left(I D_{\text {shell }} \cdot C \cdot B\right)}{S_{T}}
$$

Analisa shell side mass velocitydapat dilakukan analisa sebagai berikut:

$$
G_{s}=\frac{\dot{m}}{A_{S}}
$$

Analisa diameter equivalent $(\mathrm{De})$ shell dapat dilakukan analisa sebagai berikut:

$$
D_{e}=\frac{4\left(\frac{S_{T}^{2} \sqrt{3}}{4}-\frac{\pi d_{o}}{8}\right)}{\frac{\pi d_{o}}{2}}
$$

Sehingga didapatkan nilai koefisien konveksi pada sisi shell dengan menggunakan analisa sebagai berikut:

$$
\frac{h_{o} D_{e}}{k}=0,36\left(\frac{D_{e} G_{s}}{\mu}\right)^{0,55}\left(\frac{C_{p} \mu}{k}\right)^{\frac{1}{3}}\left(\frac{\mu_{b}}{\mu_{w}}\right)^{0,14}
$$

Setelah didapatkan nilai koefisien konveksi pada sisi shelldan pada sisi tubemaka dapat dilakukan analisa overall heat transfer coefficient sebagai berikut:

$$
\begin{gathered}
\frac{1}{U_{c a l}}=\frac{1}{h_{o}}+R_{f i}+\frac{1}{h_{i}} \\
0 \leq \frac{U_{c a l}-U_{\text {asumsi }}}{U_{\text {asumsi }}} \leq 30 \%
\end{gathered}
$$




\subsubsection{Analisa Penukar Panas}

\section{Metode Beda Temperatur Rata-Rata Logaritmik (LMTD)}

Metode yang sering digunakan untuk perancangan dan perhitungan unjuk kerja peralatan penukar panas.

$$
q=U \cdot A \cdot \Delta T_{L M T D}
$$

Harga $\Delta T_{L M T D}$ dapat ditentukan dengan mengetahui harga suhu masuk dan suhu keluar kedua fluida tersebut, sehingga persamaan di atas menjadi:

$$
\begin{gathered}
\Delta T_{L M T D}=\frac{\Delta T_{1}-\Delta T_{2}}{\ln \left(\frac{\Delta T_{1}}{\Delta T_{2}}\right)} \\
{\left[\begin{array}{l}
\Delta T_{1} \equiv T_{h, 1}-T_{c, 1}=T_{h i}-T_{c o} \\
\Delta T_{2} \equiv T_{h, 2}-T_{c, 2}=T_{h o}-T_{c i}
\end{array}\right]}
\end{gathered}
$$

Dimana:

$\mathrm{q}=$ heat transfer $(\mathrm{W}) ; \mathrm{U}=$ Overall heat transfer coefisien $\left(\mathrm{kJ} / \mathrm{s} \cdot \mathrm{m}^{2} \mathrm{~K}\right) ; \quad \mathrm{A}=\mathrm{luas}$ bidang perpindahan panas $\left(m^{2}\right)$.

\section{Metode Number of Transfer Unit (NTU)}

Metode ini lebih efektif, jika dipakai untuk mengetahui unjuk kerja dari penukar panas yang sudah jadi. Untuk mendefinisikan unjuk kerja dari penukar kalor terlebih dahuluharus diketahui laju perpindahan panas maksimum yang dimungkinkan oleh penukar kalor tersebut $\left(\mathrm{q}_{\text {maks }}\right)$

$$
\begin{aligned}
& \text { Jika } C_{c}<C_{h,} \text { maka } q_{\text {maks }}=C_{c}\left(T_{h i}-T_{c o}\right) \\
& \text { Jika } C_{c}>C_{h} \text {, maka } q_{\text {maks }}=C_{h}\left(T_{h i}-T_{c o}\right)
\end{aligned}
$$

Sedangkan effectiveness $\varepsilon$ adalah perbandingan antara laju perpindahan panas heat exchanger dengan laju perpindahan panas maksimum yang dimungkinkan.

$$
\varepsilon=\frac{q}{q_{\text {maks }}}
$$

Effectiveness merupakan bilangan tanpa dimensi dan berada dalam batas $0<\varepsilon<1$. Untuk semua heat exchanger effectiveness dapat dinyatakan:

$$
\varepsilon=f\left(N T U, \frac{C_{\text {min }}}{C_{\text {maks }}}\right)
$$
sebagai:

Number of Transfer Unit (NTU) juga merupakan bilangan tanpa dimensi dan didefinisikan

$$
N T U=\frac{U A}{C_{\min }}
$$

Dimana $\mathrm{C}_{\min }$ diperoleh untuk nilai yang terkecil dari: 


$$
\begin{aligned}
& C_{c}=\dot{m}_{c} \cdot c p_{c} \\
& \text { atau } \\
& C_{h}=\dot{m}_{h} \cdot c p_{h}
\end{aligned}
$$

Dimana:

$\mathrm{C}_{\mathrm{c}}=$ Kapasitas kalor fluida dingin, $\dot{\mathrm{m}}_{\mathrm{c}}=$ laju aliran massa fluida dingin, $\mathrm{C}_{\mathrm{c}}=$ kalor spesifik fluida dingin, $C_{h}=K a p a s i t a s$ kalor fluida panas , $\dot{m}_{h}=l a j u$ aliran massa fluida panas, $C p_{h}=k$ kalor spesifik fluida panas.

\subsubsection{Analisa Pressure Drop $(\Delta \mathrm{P})$}

\section{Pressure Drop pada sisi shell $\left(\Delta \mathbf{P}_{\text {shell }}\right)$}

Pressure drop pada sisi shell dapat ditentukan dengan menggunakan formulasi:

$$
\begin{gathered}
\Delta P_{\text {shell }}=\frac{f G_{s}^{2}\left(N_{B}+1\right) D_{s}}{2 \rho D_{e} \phi_{s}} \\
N_{b}=\frac{L}{B}-1 \\
f=\exp (0,576-0,19 \ln \mathrm{Re}) \\
\operatorname{Re}=\frac{G_{s} D_{e}}{\mu}
\end{gathered}
$$

Keterangan:

$$
\begin{array}{ll}
\mathrm{F} & : \text { Friction factor } \\
\mathrm{G}_{\mathrm{s}} & : \text { kecepatan massa } \\
\mathrm{N}_{\mathrm{b}} & : \text { Jumlah Baffle } \\
\mathrm{D}_{\mathrm{s}} & : \text { Diameter Shell } \\
\rho & : \text { Massa Jenis } \\
\mathrm{D}_{\mathrm{e}} & : \text { Diameter Equivalent }
\end{array}
$$

\section{Pressure Drop pada sisi tube $\left(\Delta \mathbf{P}_{\text {tube }}\right)$}

Pressure drop yang terjadi di dalam tube terdiri dari major losses dan minor losses. Major losses terjadi akibat adanya gesekan didalam tube sedangkan minor losses terjadi karena perubahan arah aliran di dalam tube. Major losses dapat dihitung dengan:

$$
H_{L, \text { Mayor }}=f \frac{L}{d_{i}} \frac{v^{2}}{2}
$$

Minor losses dapat dihitung dengan:

$$
H_{L, \text { Minor }}=k \frac{v^{2}}{2}
$$

Sehingga nilai pressure drop total adalah:

$$
H_{\text {total }}=\left(f \frac{L}{d_{i}}+k\right) \frac{v^{2}}{2}
$$

Maka nilai pressure drop yang terjadi adalah: 


$$
\Delta P_{\text {tube }}=H_{\text {total }} \rho
$$

\section{Hasil dan analisis / pembahasan}

Berdasarkan analisa yang telah dilakukan sesuai dengan metodologi, maka diperoleh hasil yang akan diuraikan dan dibahas dalam bagian ini.

\subsection{Analisa Perpindahan Panas Sisi Tube}

Analisa laju perpindahan panas yang terjadi pada sisi tube dilakukan terlebih dahulu dengan mendapatkan properties fluida yang mengalir pasa sisi tube menggunakan tabel tekanan sifat air jenuh berikut ini:

Tabel5.Tabel Properties Fluida pada sisi tube (Cold Fluid)

\begin{tabular}{|c|c|}
\hline \multicolumn{2}{|c|}{ Data properties sisi Tube } \\
\hline$P_{\text {tube }}$ & $270 \mathrm{~kg} / \mathrm{cm}^{2}$ \\
\hline$T_{\text {avg }}$ & $432,8 \mathrm{~K}$ \\
\hline$\mu_{\text {tube }}$ & $1,79 \times 10^{4} \mathrm{Nm} / \mathrm{s}$ \\
\hline$k_{\text {tube }}$ & $0.698 \mathrm{~W} / \mathrm{mK}$ \\
\hline$C_{p}$ & $4255.991 \mathrm{~J} / \mathrm{kgK}$ \\
\hline
\end{tabular}

Dengan melakukan analisa, didapatkan hasil perhitungan Reynolds Number sebesar 156.947,4 $\left(\mathrm{Ns} / \mathrm{m}^{2}\right)$. Sesuai dengan persamaan 5 pada bab 2.3.1, jika nilai Re $>2300$ maka dapat dikatakan aliran yang terjadi merupakan aliran turbulent. Sehingga didapatkan nilai Nusselt Number berdasarkan persamaan 8 sebesar 341,67 hingga didapatkan koefisien konveksi yang tejadi pada sisi tube sebesar 15.022,59 untuk nantinya digunakan sebagai variabel analisa perhitungan Overall Heat Transfer Koefisien. Nilai koefisien konveksi ini bergantung pada besarnya tube, konduktifitas thermal tube dan besarnya nilai Nusselt number.

\subsection{Analisa Perpindahan Panas Sisi Shell}

Proses analisa perpindahan panas pada aliran yang terjadi di sisi shell diawali dengan mendapatkan properties fluida yang mengalir pasa sisi shell menggunakan tabel tekanan sifat uap air jenuh berikut ini:

Tabel6.Tabel Data sisi Shell (Hot Fluid)

\begin{tabular}{|c|c|}
\hline \multicolumn{2}{|c|}{ Data pada sisi Shell } \\
\hline$P_{\text {shell }}$ & $8,56 \mathrm{bar}$ \\
\hline$T_{\text {avg }}$ & $515 \mathrm{~K}$ \\
\hline$\mu_{\text {shell }}$ & $1,77 \times 10^{5} \mathrm{Nm} / \mathrm{s}$ \\
\hline$k_{\text {shell }}$ & $3,79 \times 10^{2} \mathrm{~W} / \mathrm{mK}$ \\
\hline$C_{p}$ & $2207.043 \mathrm{~J} / \mathrm{kgK}$ \\
\hline
\end{tabular}


Perpindahan panas yang terjadi pada sisi shell didapatkan dengan menghitung cross flow area yang terjadi pada sisi shell dengan menggunakan persamaan pada sub bab 2.3.2 didapatkan nilai sebesar $0,416 \mathrm{~m}^{2}$, dilanjutkan dengan menghitung kecepatan aliran massa yang terjadi sebesar 145 $\left(\mathrm{kg} / \mathrm{m}^{2} \mathrm{~s}\right)$, diameter equivalen sebesar $0,018 \mathrm{~m}^{2}$ sehingga didapatkan koefisien konveksi sebesar 536,9 $\left(\mathrm{W} / \mathrm{m}^{2} \mathrm{~K}\right)$ yang nantinya digunakan untuk menghitung overall heat transfer coefficient.

Untuk mendapatkan nilai overall heat transfer coefficient sesuai dimensi yang sudah ada, maka nilai overall heat transfer coefficient asumsi paling tidak memiliki nilai yang sama dengan nilai overall heat transfer perhitungan dengan penentuan batas error sebesar 30\%. Dari perhitungan yang dilakukan dengan mengetahui nilai koefisien konveksi yang terjadi pada sisi shell dan sisi tube maka didapatkan nilai overall heat transfer coefficient sebesar 502,48 dan luasan perpindahan panas efektif sebesar 550,9 $\mathrm{m}^{2}$. Kapasitas fluida panas dihitung dengan menggunakan persamaan 17 didapatkan nilai sebesar 278.377(J/sK) dan kapasitas fluida dingin didapatkan nilai sebesar 1.381.069 (J/sK), sehingga didapatkan nilai koefisien fluida minimumnya sebesar $278.377(\mathrm{~J} / \mathrm{sK}$ ) dan nilai koefisien fluida maksimum sebesar $1.381 .069(\mathrm{~J} / \mathrm{sK})$. Perhitungan kapasitas fluida minumum ini nantinya digunakan sebagai variabel dalam perhitungan NTU. Dengan mengetahui nilai overall heat transfer coefficient, luasan perpindahan panas efektif, dan koefisien perpindahan panas minimum, maka didapatkan nilai NTU sesuai dengan persamaan 20 sebesar 0,99 .

\subsection{Nilai Effectiveness}

Unjuk kerja suatu heat exchanger dapat ditinjau dari besarnya nilai effectiveness $(\varepsilon)$. Besarnya nilai effectiveness ini berkisar antara 0 sampai dengan 1 . Semakin besar nilai effectiveness suatu heat exchanger maka kemampuan mentransfer panas dari heat exchanger ini akan semakin bagus karena nilai laju perpindahan panas aktualnya mendekati jumlah energi panas yang dapat dipindahkan. Besarnya nilai effectivenes berdasarkan kondisi aktual dapat ditunjukkan dengan menggunakan formulasi yang ada pada persamaan 22. Hasil effectiveness yang didapatkan berdasarkan analisa nilai NTU dan $\mathrm{Cr}$ adalah sebesar 0,47 . Unjuk kerja dalam bentuk effectiveness ini juga dapat diperoleh dari gambar grafik NTU fungsi effectiveness pada Cr bernilai 0,2 ditunjukkan pada Gambar 3:

Pada Gambar 3 dengan nilai NTU sebesar 0,99 dan nilai $\mathrm{Cr}$ 0,2 sehingga dapat diperoleh nilai effectiveness sebesar 0,5. Berdasarkan rumus effectiveness diperoleh nilai 0,47 sedangkan dari grafik $\mathrm{e}=\mathrm{f}(\mathrm{NTU}, \mathrm{Cr})$ diperoleh nilai effectiveness sebesar 0,5 . Dari hasil yang didapatkan menunjukkan bahwa perhitungan nilai effectivenes dengan rumus dan grafik memiliki hasil yang sedikit berbeda dimungkinkan karena keterbatasan perhitungan dalam penentuan interpolasi yang ada pada gambar grafik NTU fungsi effectiveness pada Cr.

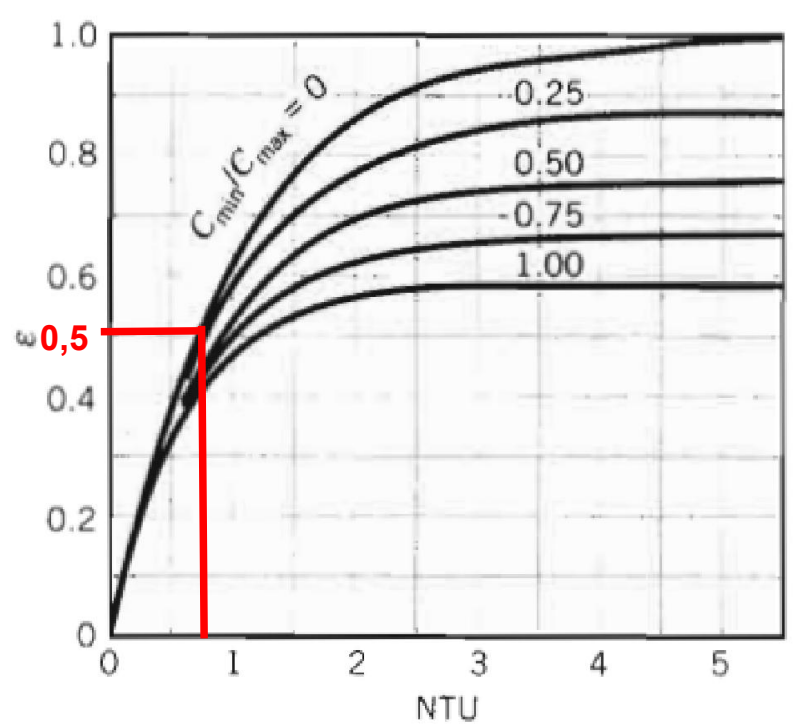

Gambar 3. Grafik NTU fungsi effectiveness pada Cr bernilai 0,2 


\subsection{Analisa Pressure Drop}

Analisa pressure drop yang terjadi pada sisi shell dapat ditentukan dengan menggunakan formulasi yang terdapat pada subbab 2.3.4dengan hasil sebesar 121,17 $\mathrm{Pa}$, sedangkan analisa pressure drop yang terjadi pada sisi tube dilakukan 2 langkah, yaitu dengan menentukan pressure drop mayor yang disebabkan karena adanya gesekan didalam tube dengan nilai sebesar 20455,96 Pa sedangkan minor losses terjadi karena perubahan arah aliran di dalam tube dengan nilai sebesar 2920,93 Pa. Sehingga pressure drop total yang terjadi pada sisi shell dengan sisi tube adalah 23.498,06 Pa.

\section{Kesimpulan}

Dari hasil analisis dan perhitungan, dapat ditarik beberapa kesimpulan mengenai laju perpindahan panas efektif, overall heat transfer coefficient, nilai effectiveness dan besarnya pressure drop pada High Pressure Heater (HPH).

1. Laju perpindahan panas

Laju perpindahan panas efektif yang terjadi pada high pressure heater memiliki nilai $37.013 \mathrm{~kW}$. Terdapat perbedaan yang cukup antara sisi shell dan sisi tube. Dengan kata lain laju perpindahan panas yang terjadi pada HPH ini dalam keadaan tidak normal. Hal ini disebabkan karena adanya ketidakseimbangan antara sisi shell dan sisi tube.

2. Overall Heat Transfer Coefficient

Nilai overall heat transfer coefficient yang terjadi pada HPH ini yaitu sebesar 502,48. Hal ini dipengaruhi oleh koefisien konveksi yang terjadi pada sisi shell dan sisi tube dengan asumsi yang menyatakan bahwa perpindahan panas secara radiasi diabaikan.

3. Nilai effectiveness

Nilai effectiveness yang dihasilkan dalam analisa perhitungan ini yaitu sebesar 0,47 . Suatu alat penukar panas akan memiliki performa yang baik ketika memiliki nilai effectiveness mendekati nilai 1 . Sehingga dalam analisa ini terjadi penurunan performa yang mungkin disebabkan oleh kondisi alat yang sudah lama dan keterlambatan dalam perawatan yang harusnya dilakukan dengan rutin.

4. Pressure Drop

Pressure drop yang terjadi pada yang terjadi pada HPH ini meliputi pressure drop yang terjadi pada sisi shell dan pressure drop yang terjadi pada sisi tube. Besarnya nilai pressure drop yang terjadi sebesar 23.498,06 Pa.

\section{Daftar Pustaka}

[1] Min Li and Alvin C.K. Lai, "Thermodynamic optimization of ground heat exchangers with single Utube by entropy generation minimization method." Energy Conversion and Management 65 (2013) 133-139, October 2012.

[2] I. Bizzi, R. Setiadi, "Studi Perhitungan Alat Penukar Kalor Tipe Shell And Tube Dengan Program Heat Transfer Research Inc.( HTRI )."JURNAL REKAYASA MESIN Vol. 13 No. 1, Maret 2013.

[3] R. Veriyawan, T.R Biyanto, G.Nugroho."Optimasi Desain Heat Exchanger Shell-And-Tube Menggunakan Metode Particle Swarm Optimization." JURNAL TEKNIK POMITS Vol. 3, No. 2, (2301-9271), 2014.

[4] J. Sudrajat. "Analisis Kinerja Heat Exchanger Shell \& Tube Pada Sistem CogBooster Di Integrated Steel Mill Krakatau." Jurnal Teknik Mesin (JTM): Vol. 06, No. 3, Juni 2017.

[5] M. Moran J and Shapiro, Howard N." Termodinamika Teknik Jilid I", edisi 4, Penerbit Erlangga, Jakarta 1994.

[6] Incropera, Frank P., Dewwit, David P., B. Theodore L, L. Adrienne S., "Fundamentals of Heat and Mass Transfer", sixth edition, John Wiley\& Sons (Asia) Pte Ltd, 2007.

[7] K. Sadik, L. Hongtan, P. Anchasa, "Heat Exchangers Selestion, Rating and Thermal Design", Third Edition, CRC Press, Taylor and Francis Group, United States of America, 2012. 